\title{
Natural Resources Law in Australia: Principles and Practices
}

\author{
Danial Kelly \\ Charles Darwin University, \\ danial.kelly@cdu.edu.au
}

\begin{abstract}
What is the jurisprudential approach taken to Natural Resources Law in Australia and how is this approach located in international jurisprudence? The ultimate source of law in Australia is Commonwealth of Australia Constitution Act however the Constitution does not specifically include an environment or natural resources power and the Commonwealth government can only make laws under the heads of power provided by the Constitution. This paper considers how natural resources law has developed as environmental protection law, especially the Environment Protection and Biodiversity Conservation Act. The discussion unearths the developing jurisprudence in Australian natural resources law that may be favouring environmental protection over human development.
\end{abstract}

Keywords: Natural resources law, environmental law, Australia

\section{A. Introduction}

The starting place for considering Natural Resources Law in Australia is the Environment Protection and Biodiversity Conservation Act 1999 (Cth) (the 'EPBC' Act). The Commonwealth of Australia Constitution Act is incredibly relevant to environmental law however there is not an environmental power within the Constitution. Therefore the Com- 
monwealth government doesn't have the ability to make a valid law on the basis of the environment. Instead it needs to rely on another head of power, such as trade (s 51(i)) or external affairs (s 51(xxix)).

For the Northern Territory of Australia the Environmental Assessment Act 2013 (NT) and the Planning Act 2017 (NT) are both highly relevant to natural resources law.

This paper will consider principles and practices of Natural Resources Law in Australia in the international context.

This research paper is presented primarily as a research preface for Indonesian academics and lawyers at the Jambi University international seminar on 'Natural Resources Law for People's Welfare' (12-13 November 2018).

\section{B. Ecologically Sustainable Development (ESD) and Normative Aspects of Sustainability}

Sustainability focuses on the capacity for humans to live within environmental constraints. ${ }^{1}$ It incorporates respect for ecological limits in affirming that economic activity must proceed within the limits of ecological systems. Indeed, ecological integrity is the very core of the concept of sustainability. Sustainability thus pre-dates the latetwentieth century concept of sustainable development. ${ }^{2}$ Sustainable development has emerged as the principal expression and application of sustainability. "Sustainable" development is economic development that is based on ecological sustainability.

Sustainability involves recognition of "the importance of biodiversity and ecological life support systems". ${ }^{3}$ The legal concept of sustainability begins with recognition that we are discussing ecological sustainability. This is made more explicitly clear in jurisdictions where "ecologically sustainable development" is the term of art used

1 John Robinson, "Squaring the Circle? Some Thoughts on the Idea of Sustainable Development” (2004) 48 Ecological Economics 369, 370

2 Klaus Bosselmann, 'Sustainability and the Courts: A Journey Yet to Begin?' (2010) 3 (1) Journal of Court Innovation 337, 338.

3 Stephen Dovers \& Robin Connor, 'Institutional and Policy Change for Sustainability' in Benjamin J Richardson \& Stepan Wood (eds), Environmental Law for Sustainability (Hart, 2006) 21- 32. 
in legislation, especially in Australian Statutes. For example, "ecologically sustainable development" is the preferred terminology in Australian statutes.

It may be said that ecologically sustainable development really forms the basis of environmental law in Australia. In the Australian context it is defined under the National Environmental Strategy (ESD) which was developed in 1992 as a response to the Earth Summit. The principles of ESD are found in the Rio Declaration. The National Strategy for Ecologically Sustainable Development defines ESD as using, conserving and enhancing the community's resources so that ecological processes in which life depends are maintained and the total quality of life now and in the future can be increased. A question that arises is 'Is ESD a legal standard that needs to be complied with?' Many courts have respected ESD as a legal principle that needs to be adhered to even though compliance can be problematic.

While ecologically sustainable development might sound like a visceral pipedream to many, the Environment Protection and Biodiversity Conservation Act 1999 (Cth) has been brave enough to give the expression legal definition for the purposes of the Act in Section 3A:

The following principles are principles of ecologically sustainable development:

a) decision-making processes should effectively integrate both longterm and short-term economic, environmental, social and equitable considerations;

b) if there are threats of serious or irreversible environmental damage, lack of full scientific certainty should not be used as a reason for postponing measures to prevent environmental degradation;

c) the principle of inter-generational equity--that the present generation should ensure that the health, diversity and productivity of the environment is maintained or enhanced for the benefit of future generations;

d) the conservation of biological diversity and ecological integrity should be a fundamental consideration in decision-making;

e) improved valuation, pricing and incentive mechanisms should be 
promoted.

Legal definition has been accomplished but clarity not. The modality of the language used and the breadth of topics over such a short distance ensure plenty of wiggle-room.

Sustainability functions as an overarching principle that prioritizes ecological concerns. It has both procedural and substantive implications. The normative aspect of sustainability is rarely discussed absent reference to certain principles, including the principle of integration; the principle of intergenerational equity, the precautionary principle, the polluter pays principle, the principle of ecological integrity, and the principle of participation. This is not to suggest that sustainability is simply an umbrella term encompassing these other principles. Sustainability has legal meaning on its own. Vaughan Lowe suggests that a useful way to approach the relationship between sustainable development and its constituent parts is to think about sustainability as a meta-principle. ${ }^{4}$ Klaus Bosselmann writes: "one premier role of the law is to promote fundamental principles, often expressed in constitutions and human rights catalogues, and ensure that the legal process is reflective of them.

If sustainability is perceived as one of such fundamental principles, the legal process will have to be reflective of it. If, by contrast, the principle of sustainability is perceived as just one of any array of environmental principles, it will compete with these and almost certainly vanish in the politics of governments still fixated on economic growth and international competition." ${ }^{5}$ For lawyers, a key question is the legal status of these principles, many of which derive from international law.

A disciplined approach to using these principles acknowledges that their legal status differs. One example is the precautionary principle, which in some legal systems is a principle of law, and in other systems is an approach that guides decision-making. In European

4 Vaughan Lowe, "Sustainable Development and Unsustainable Arguments" in Boyle \& Freestone (eds), International Law and Sustainable Development ( Oxford University Press, 1999) 19- 31.

5 Bosselmann, above n 1, 346. 
Union law, the precautionary principle has achieved constitutional recognition in the Maastricht Treaty. ${ }^{6}$ What follows is a description and some illustrations of these principles.

\section{The Precautionary Principle}

The precautionary principle means that, "[w]here there are threats of serious or irreversible damage, lack of full scientific certainty should not be used as a reason for postponing measures to prevent environmental degradation". 7 This principle asserts that in cases dealing with environmental harm, it is not necessary to await full proof or certainty of that harm. The principle has been widely accepted in many countries, including Australia.

The precautionary principle is probably one of the most important natural resources law concepts. Essentially, the precautionary principle considers that in order to protect the environment a precautionary approach shall be widely applied by the states according to their capabilities. Threats of serious or irreversible damage must be avoided. A lack of full scientific certainty shall not be used as a reason for postponing cost-effective measures to prevent environmental degradation. The precautionary principle has been used as a reason to not approve certain activities which the impacts are not fully known. In order to illustrate the natural resources law precautionary principle in the Australian context, the major case of Walker $v$ the Minister for Planning \& Ors [2007] NSWLEC 741 will be considered.

The setting for Walker $v$ Minister for Planning is an area of very low lying land between a large mountain and the sea. The distance between the top of the mountain and the sea is about two kilometers which makes it an incredibly steep and spectacular area of land. This case was brought by Mrs Walker, an environment activist, against

6 Treaty on European Union, 7 February 1992, 1757 UNTS 3, art 174, 31 ILM 247 (entered into force November 1993).

7 Canada Ltée (Spraytech Soceiété d'arrosage) v Spraytech (Town), 2001 SCC 40, [2001] 2 SCR 241 at para 31 citing Bergen Ministerial Declaration on Sustainable Development, GA Res 44/228, UN GAOR, 1990, UN Doc A/ CONF 151/PC/ 10. 
an application for a subdivision in this flood mitigation area which is prone to coastal surges. In a large storm event the area is completely inundated and the argument that was presented in court was that the minister didn't make the decision properly according to law. There was a judicial review to the effect that the decision was invalid because he failed to consider the principles of ecologically sustainable development of which the precautionary principle is directly related. The judge in the Land and Environment Court, Judge Biscoe, found that the decision was invalid because the minister had made a mistake and the minister then appealed the decision up to the Court of Appeal. Eventually the case was decided on a different matter and the subdivision did go ahead. But the case remains important as far as it provides some case law about how important ecological sustainable development is and what the precautionary principle means in law. The upshot is that the minister, when making a relevant decision, needs to consider the public interest under various pieces of environmental assessment legislation and they need to consider ESD and the precautionary principle.

\section{Intergenerational Equity}

The theory of intergenerational equity forces today's decision-makers to explicitly consider future generations. Central to the theory is the requirement that each generation use and develop its natural and cultural heritage in such a way that it can be passed onto future generations in no poorer condition than it was received. ${ }^{8}$ The principle of intergenerational equity is central to the Brundtland Report definition of sustainable development: "development that meets the needs of the present without compromising the ability of future generations to meet their own needs". ${ }^{9}$ This principle highlights the long-term timeframe inherent in sustainability decision-making. Intergenerational equity is operationalized in Australian legislation

8 See Edith Brown-Weiss, In Fairness to Future Generations (Transnational Publishers, 1989).

9 World Commission on Environment and Development, Our Common Future (Oxford University Press, 1997). 
through, for example, commitments to keep protected areas intact for future generations and requirements to sustain renewable natural resources.

\section{E. Conservation of Biological Diversity and Ecological Integrity}

While the principles of conservation of biological diversity and ecological integrity are principles of sustainable development in their own right, the operation of other elements of sustainability, such as the precautionary principle and intergenerational equity, also serve to advance these principles. ${ }^{10}$ Biological diversity describes genetic diversity, species diversity, and ecosystem diversity. ${ }^{11}$ Ecological integrity is described as "the conservation of the earth's life-support systems". It signals the need to maintain ecosystem health and ecosystem services.

\section{F. Environment-Economy Integration}

The concept of integrating environmental considerations into economic planning is pivotal to sustainable development. One commentator goes so far as to suggest that this principle of integrated decision-making is what holds the other principles together. ${ }^{12}$ The formal application of the principle of integration requires, at the very least, the collection of appropriate environmental information and the performance of appropriate environmental impact assessment. ${ }^{13}$ Integration takes seriously the need to "green" the economy

10 Hon Justice Brian J Preston, "Judicial Implementation of the Principles of Ecologically Sustainable Development in Australia and Asia” (Paper delivered at the Law Society of New South Wales Regional Presidents Meeting, Sydney, 21 July 2006), 28.

11 The components of biological diversity are discussed in John Moffet $\&$ Francois Bregha, 'The Role of Law in the Promotion of Sustainable Developmen’ (1996) $6 \mathrm{~J} \mathrm{Envtl} \mathrm{L} \mathrm{\&} \mathrm{Prac} \mathrm{1,} 5$.

12 John Dernbach, 'Achieving Sustainable Development: The Centrality and Multiple Facets of Integrated Decision-making' (2003) 10 Ind J Global Legal Studies 24, 248.

13 Philippe Sands, "International Law in the Field of Sustainable Development: Emerging Legal Principles” in Winfried Lang, ed, Sustainable Devel- 
and extends far beyond traditional environmental or resource management legislation.

\section{G. Internalization of Environmental Costs}

Internalization of environmental costs requires accounting for both the short and long-term external environmental impacts of development. ${ }^{14}$ One aspect of the internalization of environmental costs, the polluter pays principle, has been described by the Supreme Court of Canada as "firmly entrenched in environmental law in Canada". ${ }^{15}$ However, the principle of internalization of environmental costs extends beyond the polluter pays principle to require pricing that reflects full life cycle costs of producing and disposing of goods, also known as the "user pays" principle.

\section{H. Participation}

Participation is particularly critical to implementing sustainability. Sustainability depends, to a considerable degree, on the way that environmental, social and economic considerations are integrated in decision-making. Participatory rights have been articulated as including the opportunity to participate in decision-making processes, access to information and access to justice. ${ }^{16}$

These principles do not exist in isolation from one another. Indeed, courts have advanced the legal concept of sustainability by recognizing the interaction of these principles. One example of this emerges from the Land and Environment Court in New South Wales. In Gray v. The Minister for Planning, ${ }^{17}$ Justice Pain interpreted the legal

opment and International Law (London: Graham \& Trotman, 1995) 53 at 61

14 Preston, above n 11, 30.

15 Imperial Oil Ltd v Quebec (Minister of the Environment), 2003 SCC 58 at para 23, [2003] 2 SCR 624.

16 These three pillars of participation have emerged from the Aarhus Convention, signed in 1998. Convention on Access to Information, Public Participation in Decision-making and Access to Justice in Environmental Matters, 25 June 1998, 2161 UNTS 450, 38 ILM 517.

17 Rose, Anna, 'Gray v Minister for Planning: Rising Tide of Climate Change Litigation in Australia' (2007) 29(4) Sydney Law Review 725; Gray v The Min- 
concept of sustainability, through the precautionary principle and the principle of inter-generational equity, as requiring the provision of certain types of information in the environmental impact assessment process. She held that in order to account for intergenerational equity, as the statute required, an "assessment of cumulative impacts of proposed activities on the environment" ${ }^{18}$ had to be included.

\section{The International Relevance of the Concept of Sustainability}

International law is relevant in interpreting Australian statutory approaches to sustainability for a number of reasons: first, because of the presumption of conformity with international law, a rule of legal interpretation that mandates that Australian law be read consistently with international law wherever possible; ${ }^{19}$ and second, through the incorporation of customary international law and the implementation of treaties. ${ }^{20}$ The legal concept of sustainability is grounded in the historical development of international law and continues to operate in an international normative context. More pragmatically, it is also instructive to look to the practice of international courts and tribunals to understand how to operationalize the legal concept of sustainability. Two such examples will be shown below, one from the International Court of Justice and one from the Appellate Body of the World Trade Organization.

\section{J. The Gabčțkovo-Nagymaros Dam Case (Hungary/ Slovakia)}

In the Gabčțovo-Nagymaros Dam Case, the concept of sustainability is evoked by Judge Weeramantry of the International Court of Justice absent a specific treaty provision on sustainability or even

ister for Planning, [2006] NSWLEC 720.

18 Ibid 122.

$19 R v$ Hape, 2007 SCC 26 , at para53.

20 For a fuller discussion of the reception of international environmental law in Canada, see Natasha Affolder, 'Domesticating the Exotic Species: International Biodiversity Law in Canada’ (2006) 51 McGill LJ 217. 
arguments on sustainability by counsel. Judge Weeramantry drew upon the legal concept of sustainable development as an element of legal reasoning at the discretion of the court. This use is consistent with the status of sustainability as a fundamental legal principle. Judge Weeramantry explains how sustainability forces us to depart from traditional approaches to decision-making: "Throughout the ages, mankind has, for economic and other reasons, constantly interfered with nature. In the past, this was often done without consideration of the effects upon the environment. Owing to new scientific insights and to a growing awareness of the risks for mankind - for present and future generations - of pursuit of such interventions at an unconsidered and unabated pace, new norms and standards have been developed, set forth in a great number of instruments, during the last two decades. Such new norms have to be taken into consideration, and such new standards given proper weight, not only when States contemplate new activities but also when continuing with activities begun in the past. This need to reconcile economic development with protection of the environment is aptly expressed in the concept of sustainable development. For the purposes of the present case, this means that the Parties together should look afresh at the effects on the environment of the operation of the Gabčtkovo power plant."21 Judge Weeramantry asserts that sustainable development demands "looking afresh" at environmental impacts that may have been acceptable in the past.

\section{K. Shrimp-Turtle I}

This need to force decision making practices to catch up with the demands of sustainable development and the prioritization of ecological integrity is a theme that is affirmed by the Appellate Body of the WTO in its Shrimp-Turtle I decision. Shrimp-Turtle I The wording of the Preamble of the Marrakesh Agreement Establishing the World Trade Organization ("WTO Agreement") provides that WTO

21 Case Concerning the Gabcikovo-Nagymaros Project (Hungary v Slovkakia), [1997] ICJ Rep 7 at para 140. 
Members' relations in the field of trade and economic endeavors should be conducted in a way that "[allows] for the optimal use of the world's resources in accordance with the objective of sustainable development, seeking both to protect and preserve the environment and to enhance the means for doing so in a manner consistent with their respective needs and concerns at difference levels of economic development". 22

In the 1998 Shrimp-Turtle I dispute, the Appellate Body of the WTO was tasked with interpreting the meaning of "exhaustible natural resources" in Article XX (g) of GATT. The provision had been written 50 years earlier. The Appellate Body held that these words "must be read by a treaty interpreter in the light of contemporary concerns of the community of nations about the protection and conservation of the environment". ${ }^{23}$ It relied upon the preambular reference to sustainable development in the 1995 WTO Agreement quoted above in its decision: "As [the preambular reference to sustainable development] reflects the intentions of negotiators of the WTO Agreement, we believe it must add colour, texture, and shading to our interpretation of the agreements" ${ }^{24}$ Such a reading led to the interpretation that the protection of sea turtles fell within the meaning of exhaustible natural resources. These two examples illustrate that the task of clearly articulating the legal concept of sustainability remains a work in progress. It is a task being taken up by judges and court practitioners around the world. ${ }^{25}$ The legal concept of sustain-

22 Marrakesh Agreement Establishing the World Trade Organization, 15 April 1994, 1867 UNTS 154, 33 ILM 1144, at preamble.

23 WTO, Appellate Body, United States - Import Prohibition of Certain Shrimp and Shrimp Products, WTO Doc WT/DS58/AB/R (1999) at para 129, online: WTO <http:/ / docsonline.wto.org $>$.

24 Ibid 153

25 In 2002 senior judges and chief justices from around the world signed the Johannesburg Principles on the Role of Law and Sustainable Development, affirming principles that should guide the judiciary. Johannesburg Principles on the Role of Law and Sustainable Development : 'Statement adopted at the Global Judges Symposium on Sustainable Development and the Role of Law, Johannesburg, South Africa, 18-20 August 2002' (2003) 15 J Envtl L 107. 
ability is an evolving concept, but one which, at its core, affirms that economic activity happens within ecological limits.

\section{Environmental Impact Assessments}

Environmental impact assessments are tools that were set out in the Rio Declaration for protecting the environment and achieving sustainable development. Environmental impact assessment forms the basis of many statutory processes around Australia. Within the Northern Territory significant effect on the environment is one of the tests or standards of determining whether or not environmental impact assessment is required for a project or if an environmental assessment is required at all or if it simply can go ahead with no environmental assessment. The legislative basis for this is the Environmental Assessment Act 2013 (NT). Within the environmental impact assessment process there are terms of reference that the development proponent needs to meet and they meet those terms of reference and request for information by providing expert reports that are produced by scientific consultants such as an environmental consultant, an engineer, or, in some cases, an ecologist.

The information is provided to the assessment body. Once it's reviewed further information requests can be made to clarify points within those reports essentially to determine what the impact on the environment will be from either a specific aspect of the development or the whole development. A good example that you can look at is the McArthur River Mine stage three assessment which is available online. The scientific consultants who have contributed to that environmental impact statement includes engineers, hydrologists, ecologists, earth scientists, botanists, and anthropologists.

\section{Pollution and Waste}

Another particularly important area of environmental law and some of the concepts that you'll see throughout legislation is the pollution and waste idea. Pollution and waste of course is really topical within the media. Within the concept of ESD there is something called the 
'polluter pays' principle which is principle 19 of the Rio Declaration and also principle 13 that requires liability and compensation for victims of pollution and environmental damages as well as liability and compensation for those who pollute. As a result of the polluter pays and pollution and waste law in Australia there has developed an idea that if you are emitting a certain type of substance that you then need to pay for it in another way. It may be a social project that the business puts money into or the trading of carbon points and other types of pollution trading schemes. As a matter of policy and business practice this concept is also catching on in Indonesia.

Consequently, from pollution and waste we see commercialization endeavors. Are these laws only trying to prevent environmental degradation and protect human interest or is it actually there trying to protect the environment for its own purpose? Pollution law was first developed in the UK with respect to sewerage; open sewers in the street were covered and piped to reduce outbreaks of certain diseases. These days we have transboundary pollution cases between states for international parties. The Rio Declaration also deals with transboundary impacts. Within European landlocked and close neighbouring countries there's a lot of treaty law and a lot of domestic laws that deal with transboundary type pollution. Within the Australian context we're in a very different situation in that the pollution actually needs to go a fair distance before impacting one of our neighbours.

\section{N. Environmental Ethics and Standing}

There are three different ways of thinking about the environment. The first is anthropocentric and as you can probably guess from that word anthropocentric you put humans at the centre of the argument. The environment is there to serve us so why would we protect it? If there is to be protection then that protection must be to serve human purposes. Another approach is to take a biocentric view where one looks more to other life forms who may be considered to have some sort of standing and humans have some form of obligation to 
them. Probably the 'greenest' standpoint is the ecocentric and that is the intrinsic value and moral standing of the ecology expressed in 'rights of nature' type movements which are quite active within the Australian context.

A survey or relevant law reveals the jurisprudential approach that has developed in Australia. The Australian Conservation Foundation $v$ The Commonwealth 1980 (Cth) 146 CLR 493 case is a High Court decision which sets out the main test for standing.

The facts of that case were that the Australian Conservation Foundation sued the Commonwealth and some of its Ministers concerning a proposal by a company to develop land to build a tourist resort in Queensland. Approvals for the development had been given under the Environment Protection (Impact of Proposals) Act 1974 (Cth) and other relevant instruments. The Australian Conservation Foundation alleged that the decision to approve the development was made without adequately taking into account the applicable environmental impact statement. The Australian Conservation Foundation asserted the right to sue because, inter alia, of its well-known interest and high public profile in the preservation and conservation of the natural environment. The defendants applied for orders to dismiss the action on the ground that the Australian Conservation Foundation had no standing to bring the action.

The High Court held that an ordinary member of the public who had no special interest in upholding a law had no standing to prevent the violation of a public right unless there was a statutory provision that permitted them to do so and that the Australian Conservation Foundation had no special interest in the matter at hand. At the time the Australian Conservation Foundation was till a relatively new organisation.

The High Court held that "special interest" does not mean a mere intellectual or emotional interest and a belief, however strongly felt, that the law should be observed or that conduct of a particular kind should be prevented does not suffice to give its possessor standing. Rather, to enjoy standing, a plaintiff will show actual or apprehended injury or damage to his property or economic interests (see 
New South Wales Fish Authority v Phillips (1970) 1 NSWLR 725) or possibly their social or political interests.

However, in the case of North Coast Environment Council and Minister for Resources (1994) 127 ALR 617 Justice Sackville found that the Environment Council had standing as a person aggrieved because it was a peak environmental organisation in the area. It was recognised by the State and Commonwealth Government as a significant and responsible environmental organisation that had a history of coordinating projects and conferences in the area and making a submission for the government concerning environmental management and that gave it a special interest.

With the advent of s 487 of the Environment Protection and Biodiversity Conservation Act 1999 (Cth) the potential pool of parties who may have standing for the purpose of judicial review under the Act have been significantly widened.

\section{O. The EPBC Act process}

The EPBC Act is restricted in its application such that it can only deal with these matters which are of national environmental significance. These matters are generally reflective of international obligation or they're matters that have been deemed so important that they deserve a federal level of oversight. Everything else is dealt with by state and territory legislation.

How is the Act triggered? Essentially the trigger is a 'controlled action' and the definition of a 'controlled action' is one that is likely to have a significant impact on one of those matters of national environmental significance. Controlled actions can be many and varied different types of development. It might be a large mine that's definitely going to have an impact on migratory species and be right next door to a Ramsar Convention wetland. Or it might be something that's less obvious such as the development of a dam to be used by the irrigators that has fertiliser outpour which will then impact the Great Barrier Reef which is a World Heritage. The scope is large.

At the referral stage of the process there are decisions that must 
be made by the relevant minister and hence there is later scope for judicial review. When the minister receives an application they can do three different things. They can decide it is a controlled action and proceed with the assessment process, they can decide it is not a controlled action with the possibility of proceeding to assessment under other state or territory legislation, or they can decide it is a controlled action that does not require approval if it is undertaken in a particular way.

Thus the referral stage provides a rich potential for judicial review in that the minister needs to consider matters of national environmental significance. If the minister is deciding a proposed development on a Ramsar wetlands location then consideration must be given to ecological communities. If the minister is deciding a proposed development that relates to a threatened species then consideration must be given to habitat.

There are quite a few public participation opportunities under the EPBC Act. Anyone can nominate a threatened species or community listing under the EPBC Act. The public are invited to make comments and referrals of proposed actions or participate in the assessment processes. Challenges under the EPBC Act, such as injunctions or judicial review of decisions are permitted for anyone with standing under s 475 .

\section{P. EPBC Act Case Studies}

The first case that we will consider here is the Queensland Conservation Council Inc v Minister for the Environment and Heritage [2003] FCA 1463 which has become known as the 'Nathan Dams case'. This precedent decision required the Minister to consider the indirect impacts of a proposed dam.

Sudaw Developments constructed a massive dam on the Dawson River. The dam was to be used for a range of things including industrial, agricultural, urban and environmental purposes. The catchment area was very large, over 50,000 square kilometres and the dam was also significant, being 880,000 megalitres. 
The pertinent questions that were asked were what sort of environmental impacts need to be considered with respect to the definition of a controlled action? Does an impact that is likely to have a significant impact mean one that is about the actual dam, about the construction of the dam, or is it about the use of the dam? Is it about something that's right next to the dam or can it be something that's thousands of kilometres away?

Now the conservationists had argued that all impacts need to be considered and in this case it was particularly about the run-off from farms that had used the water from this particular project that would then contain fertilizer. That fertiliser moves into the waterway and goes out into the Great Barrier Reef where it causes damage to the underwater environment. Is that impact too remote to a dam that's being built thousands of kilometres away? Does that impact need to be considered by the decision maker?

The minister who made the decision did not consider all adverse impacts that are indirect consequences of the activity under consideration. Consideration was not given to the activities of third parties that the proponent does not have any control over.

The Federal Court held that the Minister does need to consider those impacts. Broad consideration must be made including considering the use of pesticides by third parties and the impacts that it will have on the Great Barrier Reef.

This decision was by a single judge of the Federal Court. The minister appealed to the full court and the full court agreed with the single judge. The full court held that impact does include direct and indirect impacts and the impact of third parties does fall within the consideration. The Minister must consider all adverse impacts including consequences which can be reasonably imputed as within the contemplation of the proponent whether or not they are undertaken by the proponent.

The Booth v Bosworth [2001] FCA 1453 case is better known as the Flying Fox case. Dr Carol Booth was the applicant in this case which relates to the electrocution of a large number of spectacled flying foxes on a lychee farm in tropical Queensland. Dr Booth was repre- 
sented by the Environmental Defenders Office of Queensland when she initiated court proceedings in an attempt to save the flying foxes. Dr Booth had a special interest in flying foxes due to her research. The defendant, Mr Bosworth, was the gentleman who owned the farm who put up the electric grids that were electrocuting the flying foxes. The farm contained a lychee orchard of about 60 hectares and the electric grid was to protect the lychees from the flying foxes.

First of all there was an injunction that sought to stop the use of the grid from electrocuting the flying foxes. The applicant, Dr Booth, contended that the action was having a significant impact on the World Heritage values of the declared World Heritage property which was the wet tropics and this contravened the EPBC Act. That is, the action was having an impact on a matter of national environmental significance, namely that the area is an outstanding example representing a major stage of the earth's evolutionary history and an outstanding example representing significant ongoing ecological and biological processes, containing important and significant natural habitats for in situ conservation of biological diversity. The reason why this case relied on the wet tropics rather than the flying foxes is because the flying foxes weren't protected under the EPBC Act but the wet tropics were.

So in order to be successful Dr Booth needed to prove that the killing of the flying foxes was likely to have a significant impact on the World Heritage values of the wet tropics area. Looking at the meaning of 'likely' in its usual understanding, means that it is probable that it's going to happen. Essentially the question is 'is the decline of the population of the flying foxes so significant that it would have a significant impact on the World Heritage values of the wet tropics area?' Within this case it was argued that the grid did cause and would continue to cause death at large scale of the flying foxes. The foxes are residents of the World Heritage area and contribute to the biodiversity ecological function and the ongoing evolutionary processes of the wet tropics World Heritage area. The spectacled flying fox contributes to the genetic diversity and biological diversity of the wet tropics area. 
In order to establish this in fact, Dr Booth visited the lychee orchard during the night on four different nights during the 2000/2001 lychee season and counted the number of dead flying foxes on the grid. She counted nearly 400 dead flying foxes a night. Dr Booth called expert evidence from a biologist who gave evidence that the lychee season in Queensland coincides with the peak of the birth and lactation period of the flying foxes and for that reason the electrocution of the flying foxes during that time was actually more significant on the species than it would be at other times of the year. After hearing all the expert evidence the court concluded that the range of flying foxes that would have been killed within that season was somewhere between 9,000 and 10,000 of about 100,000 spectacled flying foxes and that if the electrocuted grid were to continue it would cause the death of about half of the flying fox population in just five years. The court were satisfied that the flying fox contributed to the World Heritage values of the area and largely agreed with the arguments that Dr Booth put forward.

Therefore the court granted the injunction as it found there was a significant deterioration of the natural heritage values of the area to concluded that the grid operation action was likely to have a significant impact and therefore can be categorized as a controlled action. The judge noted that it is undoubtedly a matter of great public interest that the World Heritage values of the World Heritage area and biodiversity generally in that area are protected so leaving the door open and supporting this idea of public environmental litigation and having a broad standing provision.

\section{Q. Concluding Remarks}

Sustainability is a concept with legal meaning. It is a concept that recognizes the ecological limits on economic activity. The promotion of ecological integrity thus lies at its core. It is easy to understand how attempts to apply sustainability, through sustainable development, have obscured the legal meaning and significance of sustainability. Sustainable development has mistakenly been framed as contain- 
ing only the normative content of mandating balancing, requiring compromise between economic, environmental and social demands. This paper has sought to clarify these concepts and the key principles underlying sustainability. In so doing, examples of how Australian, foreign and international courts and tribunals have sought to operationalize these principles have been provided.

\section{Bibliography}

Ainsworth Lumber Co (Re), [2000] AEABD No 3.

Alan Boyle \& David Freestone,'Introduction' in Alan Boyle \& David Freestone (eds), International Law and Sustainable Development (Oxford University Press, 1999)

British Columbia v Canadian Forest Products Ltd, 2004 SCC 38 at para 7, [2004] 2 SCR 74

Canada Ltée (Spraytech Soceiété d'arrosage) v Spraytech (Town), 2001 SCC 40, [2001] 2 Bergen Ministerial Declaration on Sustainable Development, GA Res 44/228, UN GAOR, 1990, UN Doc A/CONF 151/PC/ 10

Case Concerning the Gabcikovo-Nagymaros Project (Hungary v Slovkakia), [1997] ICJ Rep 7

Chris Tollefson \& Jamie Thornback, 'Litigating the Precautionary Principle in Domestic Courts' (2008) 19 (1) J Envtl L \& Prac 33 Edith Brown-Weiss, In Fairness to Future Generations (Transnational Publishers, 1989)

Hon Justice Brian J Preston, "Judicial Implementation of the Principles of Ecologically Sustainable Development in Australia and Asia" (Paper delivered at the Law Society of New South Wales Regional Presidents Meeting, Sydney, 21 July 2006

Imperial Oil Ltd v Quebec (Minister of the Environment), 2003 SCC 58 at para 23, [2003] 2 SCR 624

Jerry DeMarco, 'Law for Future Generations: A Theory of Intergenerational Equity in Canadian Environmental Law’ (2005) $15 \mathrm{~J}$ Envtl L \& Prac 1

Johannesburg Principles on the Role of Law and Sustainable Devel- 
opment-Statement adopted at the Global Judges Symposium on Sustainable Development and the Role of Law, Johannesburg, South Africa, 18-20 August 2002' (2003) 15 J Envtl L 107

John Dernbach, 'Achieving Sustainable Development: The Centrality and Multiple Facets of Integrated Decision-making' (2003) 10 Ind J Global Legal Stud 247

John Robinson, 'Squaring the Circle? Some Thoughts on the Idea of Sustainable Development' (2004) 48 Ecological Economics 369. Klaus Bosselmann, 'Sustainability and the Courts: A Journey Yet to Begin?’ (2010) 3(1) Journal of Court Innovation 337

Klaus Bosselmann, Principles of Sustainability: Transforming Law and Governance (Ashgate Publishing Group, 2008)

Letter from Scott Vaughan, Commissioner of the Environment and Sustainable Development, to Jim Prentice, Minister of Environment (7 June 2010), online: Office of the Auditor General of Canada <http:// www.oag-bvg.gc.ca/internet/English/cesd_ fs_e_33888.html $>7$

Marrakesh Agreement Establishing the World Trade Organization, 15 April 1994, 1867 UNTS 154, 33 ILM 1144

Michael Jacobs, 'Sustainable Development as a Contested Concept' in Andrew Dobson (ed) Fairness and Futurity (Oxford University Press, 2004)

New Zealand, Ministry for the Environment, Resource Management Law Reform: Sustainability, Intrinsic Values and the Needs of Future Generations, Working Paper 24 (Wellington: Ministry for the Environment, 1989)

Philippe Sands, 'International Law in the Field of Sustainable Development: Emerging Legal Principles' in Winfried Lang, ed, Sustainable Development and International Law (Graham \& Trotman, 1995)

Stephen Dovers \& Robin Connor, 'Institutional and Policy Change for Sustainability' in Benjamin J Richardson \& Stepan Wood, eds, Environmental Law for Sustainability (Hart, 2006)

World Commission on Environment and Development, Our Common Future (Oxford University Press, 1997) 
WTO, Appellate Body, United States - Import Prohibition of Certain Shrimp and Shrimp Products, WTO Doc WT/DS58 / AB/R (1999) at para 129, online: WTO < http:/ / docsonline.wto.org> 